\title{
PENGARUH PENDIDIKAN KESEHATAN TERHADAP TINGKAT PENGETAHUAN TENTANG DIABETES MELITUS PADA MASYARAKAT DI KELURAHAN PAHANDUT PALANGKARAYA
}

\author{
Putria Carolina \\ Dosen Pengajar Program Studi S-1 Keperawatan \\ Sekolah Tinggi IImu Kesehatan Eka Harap Palangka Raya
}

Email: putria_ekaharap@yahoo.co.id

\begin{abstract}
ABSTRAK
Diabtes Melitus (DM) merupakan sindrom yang disebabkan ketidakseimbangan antara tuntutan dan suplai insulin, penyakit ini bersifat sistemis kronik dan multifaktorial yang dicirkan dengan hiperglikemia dan hiperlipidemia. Gejala yang timbul adalah akibat kurangnya sekresi insulin atau ada insulin dikaitkan dengan gangguan mikrovaskular dan makrovaskular, gangguan neuropatik dan lesi dermopatik. Penelitian ini bertujuan untuk mengetahui pengaruh pendidikan kesehatan terhadap tingkat pengetahuan tentang diabetes melitus pada masyarakat di Kelurahan Pahandut Palangka Raya. Penelitian ini menggunakan desain Pra-eksperimental dengan pendekatan one group pre-test and posttest design. Sampling dalam penelitian ini menggunakan teknik purposive sampling dan didapatkan sampel sebanyak 30 responden di Kelurahan Pahandut Palangka Raya. Pengumpulan data menggunakan alat ukur berupa kuesioner, perlakuan yang digunakan adalah pendidikan kesehatan, data dianalisa dengan menggunakan uji statistik non parametrik Wilcoxon Sign Ranks Test. Tingkat pengetahuan sebelum dilakukan pendidikan kesehatan pada masyarakat di Kelurahan Pahandut Palangka Raya diketahui bahwa dari 30 responden ada 20 responden (67\%) yang berpengetahuan kurang, 8 responden $(26 \%)$ yang berpengetahuan cukup dan 2 responden $(7 \%)$ yang berpengetahuan baik. Tingkat pengetahuan setelah diberikan pendidikan kesehatan diketahui bahwa dari 30 responden, tidak ada responden (0\%) yang berpengetahuan kurang, 8 responden (27\%) yang berpengetahuan cukup dan 22 responden $(73 \%)$ yang berpengetahuan baik. Hasil analisis melalui uji statistik diperoleh Sig. (2-tailed) 0,000 yang berarti lebih kecil dari $p$-value 0.05, sehingga didapat hasil $<p$-value $(0.000<0.05)$. Maka dapat disimpulkan ada pengaruh pendidikan kesehatan terhadap tingkat pengetahuan tentang diabetes melitus pada masyarakat di Kelurahan Pahandut Palangka Raya.
\end{abstract}

Kata Kunci: Pendidikan Kesehatan, Diabetes Melitus, Tingkat Pengetahuan

\section{ABSTRACT}

Diabtes Melitus (DM) is a syndrome caused by an imbalance between demands and supply of insulin, this disease is a chronic systemic and multifactorial disease that is excised with hyperglycemia and hyperlipidemia. Symptoms that arise are due to lack of insulin secretion or insulin associated with microvascular and macrovascular disorders, neuropathic disorders and dermopathic lesions. This study aims to determine the effect of health education on the level of knowledge about diabetes mellitus in the community in Pahandut Village, Palangka Raya.This study used a pre-experimental design with one group pre-test and post-test design approach. Sampling in this study used purposive sampling technique and obtained a sample of 30 respondents in Pahandut, Palangka Raya. Data collection used a measuring instrument in the form of a questionnaire, the treatment used was health education, data were analyzed using the non-parametric statistical test of the Wilcoxon Sign Ranks Test. The level of knowledge before health education was conducted in the community in Pahandut Palangka Raya Village, it was known that out of 30 respondents there were 20 respondents (67\%) with less knowledge, 8 respondents $(26 \%)$ who had sufficient knowledge and 2 respondents (7\%) who had good knowledge. The level of knowledge after being given health education revealed that out of 30 respondents, there 
were no respondents (0\%) who lack knowledge, 8 respondents $(27 \%)$ were knowledgeable enough and 22 respondents (73\%) were well-informed. The results of the analysis through statistical tests were obtained Sig. (2-tailed) 0,000 which means smaller than $p$-value 0.05 , so that the results obtained $<p$-value $(0.000<0.05)$. So it can be concluded that there is an effect of health education on the level of knowledge about diabetes mellitus in the community in Pahandut Palangka Raya.

Keywords: Health Education, Diabetes Mellitus, Level of Knowledge

\section{PENDAHULUAN}

Diabetes melitus (DM) adalah sekelompok kelainan heterogen yang ditandai oleh kenaikan kadar glukosa dalam darah. DM merupakan penyakit sistemis kronik dan multifaktorial yang dicirikan dengan hiperglikemia dan hiperlipidemia. Gejala yang timbul adalah akibat kurangnya sekresi insulin atau ada insulin yang dikaitkan dengan gangguan mikrovaskular dan makrovaskular, gangguan neuropatik dan lesi dermopatik. Menurut Baradero (2009), patofisiologi dari diabetes mellitus adalah apabila jumlah atau dalam fungsi/aktivitas insulin mengalami difesiensi (kekurangan I insulin, hiperglikemia akan timbul dan hiperglikemia ini adalah diabetes.

Tahun 2012 dilaporkan bahwa terdapat 1,5 juta penduduk mengalami kematian akibat DM dengan prevalensi sekitar 2,7\% Seluruh kematian akibat DM di dunia, 70\% kematian terjadi di negara-negara berkembang termasuk Indonesia. Tingkat prevalensi global penderita DM pada tahun 2014 sebesar 8,3\% dari keseluruhan penduduk di dunia dan mengalami peningkatan pada tahun 2014 menjadi 387 juta kasus [2] Tahun 2013, proporsi penduduk Indonesia yang berusia $\geq 15$ tahun dengan DM adalah 6,9 persen. Prevalensi DM yang terdiagnosis dokter tertinggi terdapat di DI Yogyakarta (3,0\%) dari 2.777.211 jumlah penduduk, DKI Jakarta
(3,0\%), dari 7.609.272 jumlah penduduk, Sulawesi Utara (2,4\%) dari 1.698.831 jumlah penduduk dan Kalimantan Timur (2,3\%), dari 2.753.491 jumlah penduduk. Prevalensi DM yang terdiagnosis dokter atau berdasarkan gejala, tertinggi terdapat di Sulawesi Tengah $(3,7 \%)$, dari 1.861 .021 jumlah penduduk, Sulawesi Utara (3,6\%) dari 1.698.831 jumlah penduduk, Sulawesi Selatan (3,4\%) dari 5.738.932 jumlah penduduk dan Nusa Tenggara Timur (3,3\%) dari 3.116.580. Data daerah Kalimantan Tengah (1,2\%) dari 1.608.217 jumlah penduduk sudah terdiagnosis dokter dan $(0,4 \%)$ belum pernah terdiagnosis DM oleh dokter tetapi dalam 1 bulan terkhir mengalami gejala sering lapar, sering haus, sering buang air kecil dalam jumlah banyak dan berat badan turun [3].

Berdasarkan hasil survey pendahuluan yang dilakukan melalui wawancara pada 10 warga masyarakat di Kelurahan Pahandut Palangka Raya terdapat 8 (80\%) keluarga memiliki pengetahuan yang kurang tentang DM dan 2 (20\%) keluarga memiliki pengetahuan yang cukup tentang DM.

DM merupakan kelainan defisiensi atau resistensi insulin yang absolute atau relative ditandai oleh gangguan metabolisme karbohidrat protein dan lemak. Ketidaktahuan masyarakat tentang penyakit DM menyebabkan banyak masyarakat yang baru mengetahui menderita penyakit DM setelah 
melakukan pemeriksaan di rumah sakit dan oleh dokter terdiagnosis menderita penyakit DM. Berpedoman pada pencegahan jauh lebih baik dari pada pengobatan, sudah selayaknya pencegahan DM harus mendapat perhatian. Salah satu cara yang terbaik untuk pencegahan ialah meningkatkan pengetahuan melalui pendidikan kesehatan bagi keluarga. Pendidikan kesehatan tersebut dapat menambah pengetahuan keluarga untuk mengetahui penyakit DM. Dalam penatalaksanaan DM terdapat lima pilar diantaranya diet, latihan, pemantauan, terapi dan pendidikan. Jika keluarga tidak mengetahui penyakit DM, penyebab, faktor resiko terkena DM, tanda dan gejala, cara pencegahan, dan penanganan DM, maka angka kejadian penyakit DM akan terus meningkat dari tahun-ketahun. Pendidikan kesehatan adalah suatu proses perubahan pada diri manusia yang ada hubungannya dengan tercapainya tujuan kesehatan perorangan, keluarga atau masyarakat. Perawat memiliki peran yang penting dalam membantu masyarakat mencegah DM yaitu melalui upaya preventif dan promotif.

Perawat memiliki peran untuk melakukan pencegah dini terhadap gangguan sistem endokrin terutama masalah DM. Dalam pengertian yang sangat luas, preventif diartikan sebagai upaya secara sengaja dilakukan untuk mencegah terjadinya gangguan, kerusakan, atau kerugian bagi seseorang atau masyarakat sedangkan promotif, perawat memberikan sosialisasi dan promosi kesehatan tentang pentingnya mengetahui, memahami penyakit DM untuk mencegah DM.

\section{METODE PENELITIAN}

Desain dalam penelitian ini adalah dengan rancangan Pra-eksperimental dengan pendekatan one Group pra-post test design yang mengungkapkan hubungan sebab akibat dengan cara melibatkan satu kelompok subjek. Kelompok subjek diobservasi sebelum dilakukan intervensi, kemudian di observasi lagi setelah dilakukan intervensi [4].

Teknik sampling dalam penelitian ini adalah purposive sampling yaitu menentukan sampel dengan pertimbangan tertentu untuk dapat memberikan data secara maksimal [5]

Tabel 1. Desain Penelitian

\begin{tabular}{cccc}
\hline Subjek & Pra & Perlakuan & $\begin{array}{c}\text { Pasca- } \\
\text { tes }\end{array}$ \\
\hline \multirow{2}{*}{ K } & O & I & Ol \\
& Wak & Waktu & Wakt \\
& tu 1 & 2 & u 3 \\
\hline
\end{tabular}

Sampel dalam penelitian ini didapatkan melalui purposive sampling yaitu sebanyak 30 responden yang tinggal di Kelurahan Pahandut Palangka Raya. Pengumpulan data penelitian ini dilakukan dengan menggunakan instrumen berupa kuisioner yang digunakan untuk mengukur tingkat pengetahuan. Kuisioner dalam penelitian ini dibuat dalam bentuk 25 pertanyaan tertutup dengan pilihan jawaban ganda (multiple choice). Uji validitas instrument dilakukan sebanyak 29 soal pertanyaan mengenai tingkat pengetahuan tentang DM, terdapat 25 pertanyaan yang memiliki nilai diatas $r$ tabel $(0,32)$ sedangkan 3 pertanyaan lainnya di bawah nilai $r$ tabel $(0,32)$.

Analisis data yang dilakukan pada hasil penelitian ini adalah analisis univariat dan 
bivariate. Hasil analisis univariat disajikan secara matematis dalam bentuk table yang gambar hasil identifikasi tingkat pengetahuan sebelum pendidikan kesehatan dan tingkat pengetahuan setelah pendidikan kesehatan. Sedangkan distribusi frekuensi responden meliputi: umur, pendidikan, pekerjaan, jenis kelamin, pernah atau tidak mendapatkan informasi tentang DM, dan sumber informasi. Analisis bivariat dilakukan untuk melihat perbedaan masing-masing variabel dependen dan independen, perbedaan dianggap bermakna bila nilai $p$ adalah <level of significance $(<5 \%=0,05)$. Analisis dataada 2 untuk uji beda berpasangan (Uji Wilcoxon).

Prinsip etika penelitian tetap dilakukan untuk melindungi subjek penelitian.

\section{HASIL PENELITIAN}

\section{Variabel Tingkat Pengetahuan (Pre- test)}

Berikut ini merupakan hasil identifikasi tingkat pengetahuan sebelum diberikan pendidikan kesehatan.

Tabel 2 Hasil identifikasi Tingkat Pengetahuan masyarakat sebelum diberikan Pendidikan Kesehatan.

\begin{tabular}{llcc}
\hline \multicolumn{1}{c}{ Variabel } & $\begin{array}{c}\text { Kate } \\
\text { gori }\end{array}$ & $\begin{array}{c}\text { Jum } \\
\text { lah }\end{array}$ & $\%$ \\
\hline Pengetahuan & Kurang & 20 & 67 \\
sebelum & Cukup & 8 & 26 \\
pendkes & Baik & 2 & 7 \\
& Total & 30 & 100 \\
\hline
\end{tabular}

Berdasarkan tabel diatas, dapat diketahui gambaran pengetahuan sebelum diberikan pendidikan kesehatan. Seluruh responden sebanyak 20 orang $(67 \%)$ yang pengetahuannya termasuk dalam kategori "Kurang" tentang penyakit diabetes melitus.

\section{Variabel Tingkat Pengetahuan (Post-Test)}

Berikut ini merupakan hasil identifikasi tingkat pengetahuan setelah diberikan pendidikan kesehatan.

Tabel 2 Hasil identifikasi Tingkat Pengetahuan masyarakat setelah diberikan Pendidikan Kesehatan.

\begin{tabular}{llcc}
\hline \multicolumn{1}{c}{ Variabel } & \multicolumn{1}{c}{$\begin{array}{c}\text { Kate } \\
\text { gori }\end{array}$} & $\begin{array}{c}\text { Jum } \\
\text { lah }\end{array}$ & $\%$ \\
\hline Pengetahuan & Kurang & 0 & 0 \\
sesudah & Cukup & 8 & 27 \\
pendkes & Baik & 22 & 73 \\
\multicolumn{2}{c}{ Total } & 30 & 100 \\
\hline
\end{tabular}

Berdasarkan tabel diatas, dapat diketahui gambaran pengetahuan setelah diberikan pendidikan kesehatan. Mayoritas sebanyak 22 orang (73\%) adalah responden yang memiliki pengetahuan dalam kategori "Baik", 8 (27\%) orang memiliki pengetahuan "Cukup" dan tidak ada responden yang memiliki pengetahuna yang "Kurang".

\section{Analisis Pengaruh Pendidikan Kesehatan Terhadap Peningkatan Tingkat Pengetahuan}

Berikut ini merupakan hasil analisis pengaruh pendidikan kesehatan terhadap tingkat pengetahuan.

Tabel 4. Analisis Pengaruh Pendidikan Kesehatan Terhadap Tingkat Pengetahuan

\begin{tabular}{lcccc}
\multicolumn{1}{c}{ Variabel } & $\mathrm{N}$ & Mean & $\begin{array}{c}\text { Std. } \\
\text { Deviation }\end{array}$ & $\begin{array}{c}\text { Asymp. } \\
\text { Sig. (2- } \\
\text { tailed) }\end{array}$ \\
\hline $\begin{array}{l}\text { Tingkat } \\
\text { Pengetahuan } \\
\text { (pre-test) }\end{array}$ & 30 & 2,63 &, 615 & \\
$\begin{array}{l}\text { Tingkat } \\
\text { Pengetahuan } \\
\text { (post-test) }\end{array}$ & 30 & 1,73 &, 450 & 0,000 \\
\hline
\end{tabular}


Berdasarkan hasil analisis uji statistic dengan menggunakan uji wilcoxon diatas dengan nilai 0,000 didapatkan $P$ Value $<\alpha$ 0,05 yang artinya $\mathrm{Ha}$ diterima yaitu ada pengaruh pendidikan kesehatan terhadap tingkat pengetahuan tentang diabetes melitus pada masyarakat di Kelurahan Pahandut Palangka Raya.

\section{PEMBAHASAN}

Tingkat Pengetahuan Sebelum dan sesudah Diberikan Pendidikan Kesehatan tentang Diabetes Melitus pada masyarakat di Kelurahan Pahandut Palangka Raya.

Hasil penelitian sebelum diberikan Pendidikan Kesehatan Tentang Diabetes Melitus menunjukan sebagian besar responden memperoleh pengetahuan kurang sebanyak 20 responden (67\%), responden yang memperoleh pengetahuan cukup sebanyak 8 responden (26\%), dan responden yang memperoleh pengetahuan baik sebanyak 2 responden (7\%). Sedangkan hasil (post-test), menunjukan bahwa responden memperoleh pengetahuan baik sebanyak 22 responden (73\%), responden yang memperoleh pengetahuan cukup sebanyak 8 responden (27\%), dan tidak ada responden yang memperoleh pengetahuan kurang $(0 \%)$.

Diabetes mellitus merupakan sekelompok kelainan heterogen yang ditandai oleh kenaikan kadar glukosa dalam darah atau hiperglikemia [6]. DM merupakan kelainan defisiensi atau resistensi insulin yang absolute atau relative ditandai oleh gangguan metabolisme karbohidrat protein dan lemak [7]. Pengetahuan adalah hasil penginderaan manusia, atau hasil tahu seseorang terhadap objek melalui indera yang dimilikinya (mata, hidung, telinga dan sebagainya sangat dipengaruhi oleh intensitas perhatian dan persepsi terhadap objek [8]. Menurut Notoatmodjo (2010:50), ada 6 tingkat pengetahuan seseorang terhadap objek yaitu mulai dari tahu (know), memahami (comprehension), aplikasi (application), analisis (analysis), sintesis (synthesis), evaluasi (evaluation).

Ada beberapa kesamaan antara fakta dan teori tingkat pengetahuan. Sebelum diberikan pendidikan kesehatan tingkat pengetahuan mengenai pencegahan diabetes melitus dominan memiliki pengetahuan yang kurang dari hasil pre-test sedangkan hasil post-test dominan memiliki pengetahuan yang baik. Kemudahan dalam memperoleh informasi memengaruhi tingkat pengetahuan seseorang. Dengan adanya kemudahan dalam memperoleh informasi melalui pendidikan kesehatan dapat membantu mempercepat masyarakat untuk memperoleh pengetahuan yang baru. Pendidikan kesehatan merupakan serangkaian upaya yang di tunjukkan untuk mempengaruhi orang lain, mulai dari individu, kelompok, keluarga dan masyarakat agar terlaksannya perilaku hidup sehat bagi individu maupun masyarakat yang lebih luas.

\section{Analisis Pengaruh pendidikan}

\section{kesehatan Terhadap Tingkat Pengetahuan}

Hasil penelitian menunjukkan adanya perubahan pada tingkat pengetahuan sebelum (pre) dan sesudah (post) diberikan pendidikan kesehatan yang dapat dilihat 
melalui hasil uji statistik didapatkan hasil signifikansi ( $p$ value) adalah 0,000 . Nilai $p$ value $(0.000)<p$ alpha $(0,05)$ maka $\mathrm{Ha}$ diterima, artinya dapat disimpulkan bahwa ada perbedaan yang signifikan antara tingkat pengetahuan masyarakat di Kelurahan Pahandut Palangka Raya sebelum dan sesudah pemberian pendidikan kesehatan.

Pendidikan kesehatan adalah proses yang direncanakan dengan sadar untuk menciptakan peluang bagi individu-individu untuk senantiasa belajar memperbaiki kesadaran (literacy) serta meningkatkan pengetahuan dan keterampilannya (life skills) demi kepentingan kesehatan. Menurut Maulana (2009), Secara umum tujuan pendidikan kesehatan adalah mengubah perilaku individu atau masyarakat di bidang kesehatan.

Menurut Budiman (2013), pengetahuan merupakan hasil dari tahu dan ini terjadi setelah orang melakukan penginderaan terhadap suatu objek tertentu. Individu mempunyai dorongan untuk ingin mengerti dengan pengalaman-pengalamannya. Ini berarti bila seseorang mempunyai sikap tertentu terhadap suatu obyek, menunjukkan tentang pengetahuan orang terhadap obyek sikap yang bersangkutan [11]

Peneliti berpendapat bahwa meningkatkan pengetahuan dapat diperoleh dari media massa, media elektronik, lingkungan serta metode penyuluhan dengan menggunakan berbagai media seperti flifchart atau metode diskusi lainnya. Semakin banyak informasi yang diterima oleh masyarakat maka pengetahuan akan semakin meningkat dengan harapan menjadi dasar dalam memandirikan masyarakat untuk hidup sehat.

\section{KESIMPULAN}

Terdapat pengaruh pada tingkat pengetahuan setelah diberikan pendidikan kesehatan dibuktikan dari hasil analisis uji statistic Wilcoxon yaitu $p$-value $0,000 \leq 0,05$ yang artinya ada pengaruh pendidikan kesehatan terhadap tingkat pengetahuan Tentang Diabetes Melitus pada masyarakat di Kelurahan Pahandut Palangka Raya.

\section{SARAN}

Hasil penelitian ini dapat menjadi sumber informasi bagi petugas kesehatan terutama perawat dalam memberikan asuhan keperawatan pada tatanan komunitas terkait pendidikan kesehatan terhadap tingkat pengetahuan tentang Diabetes Melitus. Hasil penelitian ini dapat dijadikan sebagai sumber data bagi petugas kesehatan di Puskesmas untuk dilakukan tindak lanjut bagi masyarakat dalam rangka meningkatkan derajat kesehatan yang optimal.

\section{DAFTAR PUSTAKA}

1. Baradero, Mary, dkk. 2009. Seri Asuhan Keperawtan Klien Gangguan Endokrin. Jakarta EGC

2. Ni Putu M. A, dkk. 2015. Pengaruh Pendidikan Kesehatan TerhadapTingkat Pengetahuan Pasien Diabetes Melitus Tipe 2 Dalam Pencegahan Ulkus Kaki Diabetik DiPoliklinik Rsud Panembahan Senopati Bantul. Jurnal Universitas Respati Yogyakarta. Vol II No. 1 Maret 2015

3. Kemenkes riset kesehatan dasar: Riskesdas. 2013. Badan Penelitian Dan Pengembangan Kesehatan Kementrian RI. Jakarta. 
4. Nursalam. 2017. Metodologi Penelitian IImu Keperawatan Edisi 4. Jakarta: Salemba Medika.

5. Arikunto, Suharsimi. 2010. Prosedur Penelitian: Suatu Pendekatan Praktis. Jakarta: Rineka Cipta.

6. Smeltzer and Bare. 2002. Buku Ajar Keperawatan Medikal Bedah Edisi 8 vol. 2.Soegondo, Sidartawan, dkk. 2009. Penatalaksaan diabetes mellitus terpadu. Jakarta: Balai Penerbitan FKUI.

7. Hartono, Andri. 2012. Buku saku keperawatan pasien dengan gangguan fungsi endokrin. Tenggerang selatan. Binarupa Aksara.

8. Notoadmojo. 2010. Promosi Kesehatan Dan perilaku Kesehatan. Jakarta: PT. Rineka Cipta.

9. Maulana. 2009. Promosi Kesehatan. Jakarta: EGC.

10. Budiman \& Agus. 2013. Kapita Selekta Kuesioner.Jakarta: Salemba Medika

11. Notoadmojo. 2012. Promosi Kesehatan Dan perilaku Kesehatan. Jakarta: PT. Rineka Cipta. 